\title{
ISLAM AND LOCAL CULTURE \\ The Peril of State Violence and Hallyu Fandom in Indonesia (With Reference to Palestine) ${ }^{*}$
}

\author{
Ingyu Oh \\ Research Institute of Korean Studies \\ Korea University \\ oingyu@korea.ac.kr
}

\begin{abstract}
The invasion of Hallyu (or the Korean Wave) subculture in Indonesia created a new pattern of gendered cultural consumption in the largest Islam country in the world. The most ardent Hallyu supporters in Indonesia are women who are organizing massive urban fan gatherings, K-pop concerts, and group tours to Seoul. With a long and devastating record of state violence on Marxists, Chinese, and women in general, current public tolerance to Hallyu by the Indonesian government seems flimsy as female Hallyu fandom is threatening the mainstream Islamic value of feminine subservience. Although the strength of the local culture vis-à-vis Islam in Indonesia allowed an easy invasion of Hallyu into the country, the gender divide in the consumption of Hallyu is providing the Islam leaders with an easy excuse for possible state violence against women. Unlike Islamic, Western, and Japanese culture that are widely popular in the country, Hallyu's salient feminine following invites jealous and alarmed reactions from Indonesian Muslim males. As the Japanese and Chinese anti-Hallyu sentiments among the male population led to massive outbreaks of anti-Korean hate speeches and demonstrations against the Korean residents and Hallyu promoters in the two countries, this paper analyzes how the female fans in Indonesia and Palestine are reacting to such threats.
\end{abstract}

\section{Keywords}

Anti-Hallyu sentiments, Hallyu, Indonesia, Islam, local culture, state violence

\begin{abstract}
About the Author
Ingyu Oh is Professor of Korean Studies at Korea University. His research interests are the Korean Wave (Hallyu), gender and ethnic segregations, and political corruption. He is cofounder of the World Association of Hallyu Studies, where he currently serves the president.
\end{abstract}




\section{INTRODUCTION}

Few people have imagined that South Korean (hereafter, Korea or Korean) culture would ever attract non-Koreans. Even fewer people have envisaged that Korean popular culture would mesmerize Muslim youths in such faraway places as Turkey, Palestine, Morocco, Saudi Arabia, UAE, and Egypt. Since the rapid spread of Korean popular culture or Hallyu throughout the world through the Internet and electronic devices, including personal computers, laptop computers, and smart phones, Hallyu is now a common cultural decorum among the youths in Islam nations, including Indonesia, the largest Muslim country in the world. ${ }^{2}$ Of course, the popularity of Hallyu among the Muslim youths does not mean that Korean pop culture has replaced Islam as the mainstream cultural content in each Islam nation. Even during the unprecedented peak in its attractiveness among nonKoreans, Hallyu was a mere subculture phenomenon among minority groups in their society (see inter alia, Hübinette; Hwang; Oh and Lee; Otmazgin and Lyan).

For the seemingly impossible global pop culture phenomenon in the early $21^{\text {st }}$ century, wherein unlikely countries like Korea sell its pop culture content en masse to the fans all over the world, critics and pundits of popular culture began pouring out their polemics either in support or in disdain of the new pattern of cultural consumption among the youths within Islam nations. Particularly powerful, yet misleading, is the very view by some that Hallyu is a cultural invasion into economically backward areas of the Middle East and Southeast Asia (Huang). To many, this is a gross misunderstanding of the new global pop culture phenomenon (for example, Iwabuchi). Portraying the Korean cultural export to Islam and other nations as an invasion is a deliberate attempt to discourage and vilify third world (or formerly third world) cultural movements and their industries that attempt to preserve its local culture from Hollywood, European, and the Japanese entertainment industries. Pundits who argue that Japanese dramas and American Sci-Fi movies are far better in quality than the Korean counterparts are the very imperialists who want to defend the niche of the Japanese and American cultural industries that want to dominate every corner of the world, including poor regions of Asia (Iwabuchi). Furthermore, no one would accept a similarly mindless argument that the phenomenal success of the reggae and hip-hop music in the U.S. and Europe is a cultural invasion by Jamaicans. Third World music only enriches local pop culture content, just as black music had done for American white culture (Floyd).

The popularity of Hallyu among the Islamic youths, especially among young women, poses many new questions about Korean pop culture. First and foremost, their choice to consume Hallyu in Indonesia and non-Arabic Islam countries is not because of the Korean cultural invasion into their nations (in a similar fashion 
to the invasion of Islam and Christianity) but because of their voluntary embrace of an exotic pop culture that they actively wanted to promote in their own region through informal digital means (e.g., YouTube, Facebook, internet fan sites, etc.). They actively promoted Hallyu in their own countries because Korea was a rare success case of development from the ashes of war and/or colonial oppressions (as evidenced by the interviews with Indonesian and Palestinian fans presented in this paper). Simultaneously, Korea has been one of the most pro-Islam countries in the world, as its economy has heavily depended on Middle Eastern crude oil and demands of Korean construction and shipbuilding services from Islamic countries in Asia and Africa, not to mention the Middle East (Salameh).

Korea's new soft power therefore leads to a thorny question of the relationship between cultural desires among young Islamic women and Korean pop culture. Does Hallyu deliver a new cultural message to the Muslim youths (predominantly female), who yearn for cultural liberation from oppressions of all kinds? This bold question may sound as equivocal as the question of finding a fundamental and therefore universal cultural value for women that can undercut the entire Islam world more than Islam can. It is within the purview of this paper that the above question awaits an immediate answer so that we can understand a new gendered political discourse among female Islam Hallyu fans for their universal existence as free female beings vis-à-vis stereotyped Islam women portrayed in the practiced version of daily Quran (El Feki).

Second, we still need to go back to the old question of whether Islam is a cultural mandate for all human beings living in the Muslim world, including Indonesians (Kobayashi). Or is Islam yet another foreign culture that had so successfully invaded different nations culturally that local people lost the sense of its foreignness? In fact, this question is an old one that intrigued many colonial scholars who wrote about Islam and local cultures in their colonies. In Indonesia, for example, Dutch colonial scholar Christian Snouck Hurgronj argued that Indonesia had a "soft" version of Islam that was different from the mainstream tenet found in the Middle East (Kobayashi; Carvalho). In a similar vein, Geertz argued that the Indonesian cultural practice of Islam was far different from that of Morocco's, highlighting the importance of local culture ("The Javanese Kijaji"; The Religion of Java). He further developed the concept of soft and diverse "Islamism" in Indonesia (e.g., abangan, santri, priyai), whereas local culture would remain homogenous (Steenbrink; Nakamura). Therefore, the uneasy cohabitation between Islam qua universal culture and local cultures as quintessentially banal variations in different Islam nations have continuously posed a profound theoretical question as to whether the embrace of Islam by localities is relative to the strength and/or peculiarity of local conditions. The subsequent encounters with Western colonialism, Japanese pop culture, and Hallyu in Islam nations, particularly in Malaysia and Indonesia, during 
both colonial and post-colonial periods might have brought in different magnitudes of affection and consumption of these non-Islam (or sometimes counter-Islam) norms and values. Even if most Islam nations did embrace Hallyu, we still want to know whether the consumption pattern of Hallyu would differ from one locale to another.

These two seemingly unrelated questions of Islam and the voluntary embrace of Hallyu among the Islam youths in many different Islamic countries may cause confusion, although it should not be as perplexing as any other religious and cultural convolutions. The relativistic understanding of Islam, or any other arguments that emphasize the importance of local culture (e.g., Tsuchiya) continues to elide the devastating aspect of Islam to its selected populations, such as ethnic minorities (e.g., Kurds in Turkey and Iraq, black Africans in North Africa and the Middle East, Chinese in Malaysia and Indonesia) and women (Aguilar; Heryanto and Hadiz; Naramoto; Heryanto). As these writers have clearly documented and analyzed, Islam states, like their counterparts in secular states, have massacred, jailed, and physically oppressed both male and female bodies in the course of modernization and state building. Soldiers of the Pinochet regime committed mass rapes during the military coup in 1973, while President Duterte of the Philippines either jokingly or seriously endorses his solders' mass rape of women in their fight against the Islam insurgency in Mindanao. Indonesia has not been an exception, as Suharto's military coup and his regime had routinely arrested, massacred, and mass raped ethnic minorities and communists.

The first question of women's desire to be free from state violence of all types is therefore quintessentially a question of their survival. Gender inequality and the oppression of and violence against women are so widespread that the importance of local culture is deemed meaningless-all local cultures in the Islam countries seem to discriminate against women. Demanding data on gender discrimination itself is a lame effort to cover up male domination in these countries. Having said that, however, we still notice that local cultures affect the patterns and magnitudes of Hallyu consumption, although the cultural consequence of the consumption as such (i.e., desire to travel Korea, desire to consume more Korean pop culture content, or desire to be free as women) for the young women would not vary significantly between Indonesia and any other Islam countries as this study indicates.

A key mechanism in the understanding of the uneasy cohabitation between the universal gender strife under Islam and local culture is the magnitude of state violence on the minority groups. It may as well be more logical to assume that local cultures affect the structure of tolerance, equality, and the use/avoidance of state violence on its own people within each Islamic society than to shoulder that local culture has no effect on tolerance. In other words, gender oppression is 
universal, whereas state violence is not. For example, police violence in America appears appalling to U.K. citizens, who are accustomed to unarmed constables. One can easily assume that any challenge to Islam (e.g., demanding new gender relations) would automatically invite the use of state violence on women. This probably was why Geertz once noticed that local culture was homogenous in Indonesia, even though it is not, given the large number of the oppressed Chinese and non-Javanese people (The Religion of Java). One can also explain the same phenomenon differently. The state violence was too intimidating to diverse ethnic groups to maintain and display their own cultural hybridity. However, as this paper intends to demonstrate, the magnitude of state violence again depends on local culture, as Indonesia seems much more tolerant to cultural diversity than Morocco, for example (Geertz, Islam Observed).

This paper premises that Islam has not been strictly institutionalized in Indonesia, resulting in the relative strength of local culture. This also augurs that resistance to Islam and the embrace of competing cultures would have been easier for average Indonesians than others in the same Islam culture zone due to strong local culture. Finally, this leads to a possible hypothesis that the Indonesian state had to resort to violence more harshly and more often than its counterparts in the same Islam zone to solidify Islam, because its population has remained more culturally boisterous (i.e., more conscious about the foreignness of Islam itself vis-à-vis local and ethnic cultures) than other Islamic populations. This paper intends to detect differences in Hallyu fandom in Indonesia from its counterparts in the same Islamic culture zone to corroborate the hypothesis that the strength of local culture vis-à-vis Islam may lead to the clue to explaining such differences. In Indonesia, like others in the rest of the world, the most ardent Hallyu fans are young women, although Indonesia seems much more widespread and diverse in fandom composition than other Islamic countries as Palestine.

This paper first explains in detail the gender divide and its impact on Hallyu soft power, followed by a short analysis of local cultural variations in Indonesia and Palestine to measure the differences of Hallyu soft power in the two regions. The soft power case clearly illustrates the existence of the gender divide in Hallyu consumption. The paper then focuses on the role of state violence in explaining different magnitudes of Hallyu consumption in Indonesia with a comparative case of Palestine. Finally, I discuss potential threats to Hallyu soft power in Islam nations: a possible state violence on the consumers of Hallyu. This paper heavily utilizes the interviews with various Hallyu supporters in Indonesia (and Palestine in a smaller scale), which took place throughout 2013 and 2016. A qualitative study of Indonesian Hallyu fans focuses on their gender and ethnic concerns in the world's largest Islamic society, while I simultaneously measure differing degrees of personal assessment about state violence against and suppression of women and 
ethnic minorities (e.g., Chinese), which I believe are connected to both gender and ethnic variables. The paper concludes with a short discussion of Hallyu soft power in Indonesia.

\section{HALLYU SOFT POWER AND THE GENDER/ETHNICITY DIVIDE}

It is not totally true that the Korean government has not tried to use its culture to influence other nationalities through what many call the soft power public diplomacy. However, the Korean soft power public diplomacy failed to notice the linkage between soft power and the gender divide. Accordingly, Korean public diplomacy has produced mixed results throughout the Roh and Lee administrations, even as the main thrust of Korea's public diplomacy drive tried to foster a new and positive national brand among Westerners (including the Japanese) for a country that had been dubbed by many in the West and Japan as a corrupt and dictatorial country.

A typical misconception among students of soft power is that branding a new national image is similar to branding commodities. While commodities are branded based on what they promise to deliver through elocutionary acts in the mass media, national images are dispensed based on what states actually do, rather than what they say (Anholt). To Japanese elites, for example, what the Korean government promises to do (e.g., to foster friendship with Japan for future generations) and what they actually do (e.g., the presidential visit to Dokdo Island) are very contradictory to each other. Therefore, the recent BBC poll reveals that the countries that showed enormous affection and support toward Korea were not Western countries or Japan, but Indonesia, Chile, Ghana, Nigeria, and other developing countries. Korea even ranked behind China in terms of national branding (BBC World Service). These developing nations embrace Korean soft power more than Western nations and Japan, because the former admire Korea's actual track record of development and democratization, which may not seem as impressive to Westerners or the Japanese as they are to other developing countries.

Part of the reason for the failure to boost the Korean national brand among mainstream Western nations is the Korean government's heavy reliance on elitecentered branding efforts (Hall and Smith). Instead of targeting the public of Western nations and Japan (i.e., public diplomacy), the Korean branding programs approached opinion leaders of Western and Japanese societies, including foreign students, to help promote Korea in their own countries. However, opinion leaders and students do not necessarily represent the entire public of their nations. Although Western and Japanese elites can be co-opted in the Korean branding campaign, 
they would not necessarily deliver pro-Korea messages to their mainstream mass media in their own countries, contrary to the wish of the Korean government. For example, Prime Minister Abe Shinzō gave a strong pro-Korea speech and promised to work for the betterment of Korea-Japan relations during the conferral ceremony of his honorary Ph.D. degree at Woosong University in Korea in 2008. His wife, Akie, a once fervent Hallyu fan, also visited the university routinely before the inauguration of the second Abe cabinet. However, he is now an avid supporter of ultranationalism in Japan. In fact, despite all these public relations stunts, the overall Japanese perception of Korea remains very negative (Hwang). Furthermore, students can always reinforce their nationalistic penchant even after a long period of education in Korea. The largest group of foreign students in Korea has consistently been the Chinese since the diplomatic normalization between the two countries in 1992. However, the Chinese perception of Korea has actually deteriorated over the years (Gries et al.; Hall and Smith), culminating into the current Thad fiasco between the two nations.

The soft power diplomacy made a slight turn from the elite-student focused efforts to Hallyu-centered strategies in 2009 when the Lee administration established the Presidential Council on Nation Branding (PCNB). This approach enthusiastically utilized and dispatched K-pop idols and boy/girl bands to Europe, North America, and other parts of the world with substantial government support in terms of human resources, foreign services, and financial assistance. However, the PCNBled Hallyu also failed to realize an important fact that only the subculture groups in the West and Asia did massively consume Hallyu, not the mainstream elite groups. In addition, the Lee administration's K-culture policy, which encompassed both modern and pre-modern Korean culture, wrongly included Korean food, hoping to market it globally in a similar fashion to the Japanese sushi and Thai food that had conquered the world (Elfving-Hwang). The disastrous outcome of the Korean food campaign during the K-pop and K-drama peak, was a well-known tragic saga in Korea, which cost the government more than 23.6 billion won (or \$23.6 million) in less than two years between 2010 and 2011 (Hall).

The government-led public or cultural diplomacy was based on two noticeable assumptions that were nothing but untrue. First, the Lee administration, following the advice of misinformed consultants, naively accepted an incorrect view that Korea was a "middle power" country, a concept that became popular in Korea due to Andrew Cooper's seminal work (Cooper et al.). Proponents of middle power diplomacy argued that Korea was a middle power country preordained by its economic, military, and population size (Sohn). This is a gross underestimation of Korea, given the astounding fact that it is one of the seven countries in the world that passed the test of $\$ 20,000$ per capita GDP with a population of 50 million (the 20-50 club) by 2012. In addition, Korea became the 24th member of the 
prestigious Development Assistance Committee (DAC) club of the OECD in 2009. Therefore, contrary to middle power theory which overlaps the belief that Korea can be as attractive as Canada, Switzerland, or Australia, the Korean soft power diplomacy might be deemed imperialistic to the elites and ordinary people in many developing countries, especially in China and Southeast Asia, if Korea pursued a fervent cultural diplomacy in a fashion similar to Japan's soft power policy during the 1980 os (Huang).

Second, the middle power theory fails to distinguish mainstream culture from that of subculture as a tool of middle power public diplomacy. As I have mentioned earlier, Hallyu is a subcultural phenomenon in the Middle East and many other countries in the world, as the majority Hallyu supporters are women and/or ethnic minorities. In the case of Japan, for example, the gender divide in Hallyu consumption and its impact on Korean national branding is too clear to deny (see Tables 1 and 2).

Table 1: Demographic Composition of Hallyu Consumption in Japan

\begin{tabular}{llllllll}
\hline \multicolumn{7}{c}{ Gender } & \multicolumn{7}{c}{ Age } \\
\hline Buying Pattern & Male & Female & $20 \mathrm{~s}$ & $30 \mathrm{~s}$ & $40 \mathrm{~s}$ & $50 \mathrm{~s}$ & $60 \mathrm{~s}$ \\
Rarely consume & $34.4 \%$ & 21.9 & 29.8 & 33.8 & 25 & 21.7 & 26 \\
Sometimes & 52.1 & 50.6 & 56.2 & 55 & 51.4 & 44.6 & 46.6 \\
Frequently & 13.5 & 27.4 & 14 & 11.3 & 23.6 & 33.7 & 27.4 \\
\hline Total & $192 / 100$ & $237 / 99.9$ & $121 / 100$ & $80 / 100$ & $72 / 100$ & $83 / 100$ & $73 / 100$ \\
\hline
\end{tabular}

Source: Han (170)

Table 2: Perception Changes among Japanese before and after Hallyu Boom

\begin{tabular}{lllllllllll} 
& \multicolumn{3}{c}{ Before Hallyu Boom } & \multicolumn{1}{c}{ After Hallyu Boom } \\
\hline Scale & 1 & 2 & 3 & 4 & 5 & 1 & 2 & 3 & 4 & 5 \\
Male & $1.5 \%$ & 9.2 & 4.4 & 6.7 & 0.3 & 0.2 & 5.1 & 0.3 & 4.3 & 5.1 \\
Female & 3.1 & 1.1 & 1.8 & 5.2 & 0.9 & 0.1 & 0.8 & 6.2 & 7.6 & 7.4 \\
\hline
\end{tabular}

Note: On this scale, 1 means the worst and 5 means the best perception of Korea by the Japanese.

Source: Modified from Han (188). 
As Table 1 shows, the number of female supporters who frequently consume Hallyu in Japan is twice the number of male supporters. Furthermore, it is discernible from the same table that women in the age bracket of 40 os to 6os are the main consumers of Hallyu. Therefore, if the Korean government promoted Hallyu soft power diplomacy in Japan and elsewhere by targeting the mainstream population (i.e., male and elite women), it would only exacerbate the problem with Korean national branding, eventually fanning and fueling the anti-Hallyu protests.

Table 2 also confirms the fact that it was the women who showed the largest drop among the respondents who had the worst perception of Korea after their exposure to Hallyu (i.e., from $3.1 \%$ to $0.1 \%$ ), while it was also the women who exhibited the largest increase in the bracket of respondents who had the best perception of Korea after their Hallyu experience (i.e., from 0.9\% to 7.4\%). Therefore, the middle power theory that wrongly placed Korea in the global middle power group and hence recommended elite or student based soft power cultural diplomacy in China, Japan, Europe, Oceania, and North America brought in unintended consequences, especially in the form of anti-Hallyu movements of varying degrees in Japan, China, Vietnam, Malaysia, and other countries. However, Indonesia, Chile, Ghana, and Nigeria, where their publics had not experienced the Korean government's Hallyu soft power diplomacy directly, ironically flaunted increasing attraction to Korea and its culture. In this sense, anti-Hallyu movements in Japan and China are direct indications of how state violence and/or state sponsored violence against a foreign culture and its consumers can destroy cultural waves of all sorts.

Having explained why Hallyu soft power as a public diplomacy pitch during the two administrations preceding the impeached Park administration has produced unintended consequences by neglecting gender/ethnic divides, we now analyze Hallyu soft power in Indonesia with a comparative case in Palestine.

\section{HALLYU IN ISLAM NATIONS}

Indonesia and Palestine are two important Islamic nations despite their vast differences in political economic structures, culture, languages, and geographical locations. Indonesia is the largest Islam country in the world with a population size of 252.8 million, whereas Palestine is barely an independent state with only regional self-rule without full UN representation as a recognized member state (Naramoto). Despite wide differences in state institutions, local culture, and geographical locations, these two nations have formed grass roots Hallyu movement among young women in both urban and rural areas. As Table 3 indicates, the number of Hallyu fan clubs and their registered members in major Islamic countries in 
the world have continuously and increasingly expanded from 2014 without Korean public diplomacy in the region, indicating their widened consumption bases of Hallyu ranging from Korean TV dramas, Korean fashion, Korean food, and to K-pop (Kim et al.; Otmazgin and Lyan). Given the strict gender segregation in social relations, most club members in the Islam countries are female only, except in Indonesia due to a huge number of Hallyu fans who are Chinese.

Table 3: Total Hallyu Club Members in Islam Nations

\begin{tabular}{llll} 
& $\mathbf{2 0 1 4}$ & $\mathbf{2 0 1 5}$ & $\mathbf{2 0 1 6}$ \\
\hline Egypt & 59,938 & 109,533 & 128,288 \\
Tunisia & 13,700 & 13,700 & 14,500 \\
Algeria & 306 & 13,442 & 12,146 \\
Morocco & 4,040 & 4,040 & 12,050 \\
Jordan & 4,825 & 4,825 & 10,681 \\
UAE & 1,915 & 4,362 & 3,612 \\
Iraq & 1,285 & 1,285 & 1,285 \\
Kuwait & 360 & 360 & 500 \\
Saudi Arabia & 43 & 43 & 0 \\
Indonesia & 232,798 & 663,062 & 853,728 \\
\hline
\end{tabular}

Source: Korea Foundation (2014-2016)

The similarities amidst vast differences of the two countries are not limited to the recent Hallyu phenomenon. Indeed, both Indonesia and Palestine have been subject to foreign cultural invasions throughout their long history. Islam was a fundamentally foreign culture to both nations, as Arab countries through political, economic, and military means forcibly or semi-forcibly introduced the religion. Simultaneously, Islam was a fundamental ideological basis with which to fight Western imperialism that destroyed the Islam political structure of the two nations. Postcolonial experiences in these two countries were also similar, in that Palestine had to suffer from the militarist occupation of their land by the immigrant Jews, while Indonesia had to suffer from military coups d'état and state violence against the Chinese, Marxists, and other ethnic minorities (Naramoto; Heryanto). The reason these two nations were subject to foreign invasions and continuous conflicts with foreign cultures and migrants is their geopolitical location that connects between cultural and economic centers (the Roman Empire, the Arab Empires, the Osman Empire, the Chinese Empire) and natural and agrarian resources (gold, silver, silk, 
tea, pepper, gum, etc.). This means that both Palestine and Java were cultural, economic, and trade centers of the region that was further connected to the longdistance trade in the pre-modern and modern era. It is therefore not surprising that both Palestine and Java were wealthy cosmopolitan societies with significant levels of tolerance to foreign cultures (Boxer; Andaya; Doumani; Hirosue; Naramoto).

The historical background of Palestine and Java provides us with an initial clue to why both Islam countries with colossal geographical and cultural differences have produced a Hallyu subculture among their young women. This linkage between regional history and Hallyu augurs a new theoretical hypothesis that the issue of gender has been neglected in the study of the conflict between Islam and local culture on the one hand and local culture and imported culture on the other. Hallyu to them is a new foreign cultural product that is in full competition with the previous ones in the local pop culture market. Therefore, a comparative study of Palestine and Indonesia provides us with clues to the role of the gender divide in different societies in the world in Hallyu consumption and soft power, while Islam and other foreign cultures are controlled historically and geographically. At the same time, the comparison of Indonesia and Palestine would also reveal a
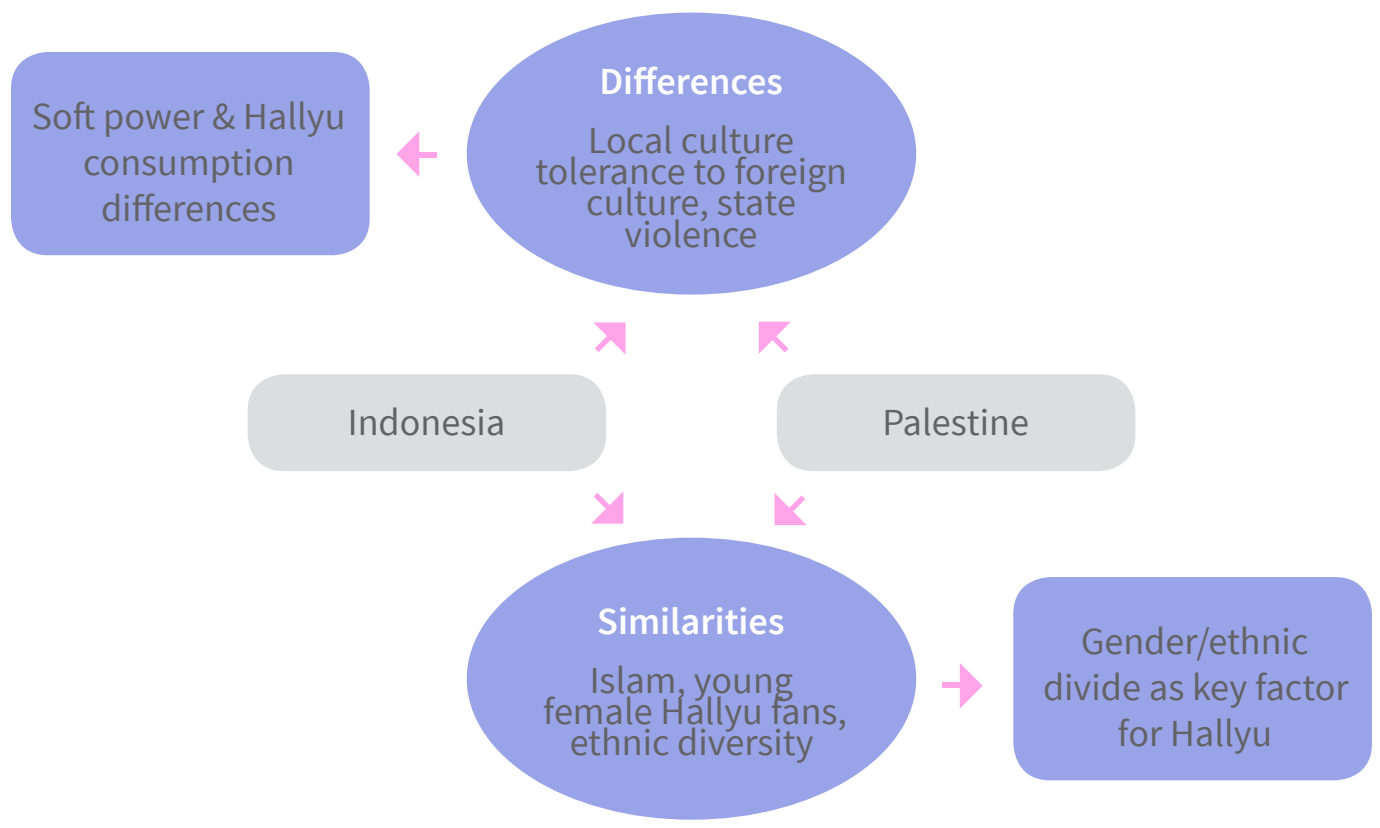

Fig. 1. Comparative Framework of Islam Hallyu 
neglected mechanism of state violence on imported cultures and their consumers in Islam societies.

These two cases shed light on both similarities (i.e., Islam, young women, ethnic compositions) and dissimilarities (local culture, tolerance to foreign culture, state violence) of Hallyu subculture movements in each case. Through this similaritydissimilarity comparative analysis, I want to find out whether gender-ethnic divides are real in these two countries as a single most important facilitator of accepting Hallyu as a new cultural symbol of liberation from internal oppressions. I also want to know whether dissimilarity factors of local culture, tolerance, and state violence can explain the differences in Hallyu soft power perceptions and Hallyu consumptions in Indonesia and Palestine.

Both Indonesia and Palestine are multiethnic societies. Palestinians comprise a political minority group within the state of Israel, which in and of itself is a multicultural and multiethnic society composed of various groups of Jews, Arabs, and Bedouins (these terms refer to cultural, not biological, ethnicity). In Indonesia, the Javanese control of other ethnic minorities in the island nation, such as Sumatrans and the Chinese, has been the norm (Samson; Suryadinata; Lev). Palestinians are to Jews what Chinese are to the Javanese. Mainstream Jews uphold Judaic religious values, whereas the majority of Palestinians are Muslims. The situation is the opposite in Indonesia, where Muslims are the mainstream vis-à-vis the Chinese who practice either Chinese Confucianism or Christianity. Therefore, as Table 4 shows, both Palestinian and Chinese women face double discrimination qua the second sex and Muslims/Chinese in their society, whereas Javanese and Jewish women face only gender discriminations.

Various empirical studies indicate that young women in Indonesia and Palestine form the majority of Hallyu fans (Kim et al.; KOFICE; Otmazgin and Lyan), although in Japan it is the middle-aged women, as we have already explained above. This difference between Japan and Islam nations is due to their dissimilar motivations toward learning foreign cultures (Oh, "Hallyu", "Torn Between"). ${ }^{3}$ In recent Indonesian fandom surveys, both Chinese and Javanese young women have formed a strong Hallyu fandom base throughout Java, whereas male and older generation Muslim populations have not formed similar fandom for the Korean subculture (KOFICE). Similarly, in recent Israeli fandom surveys, we can find comparable data that indicates a relatively strong Hallyu fandom base among young Israeli and Palestinian women in their high teens and early twenties (KOFICE; Otmazgin and Lyan). It is also found by the surveys of various years that the fandom base among the Islam populations in Indonesia and Palestine, and non-Islam populations in Israel and Indonesia have been expanding continuously since the 2010s, even 
though strong anti-Hallyu or anti-Korean sentiments are rapidly spreading in China, Japan, and other countries in Southeast Asia (Huang; Hwang).

Therefore, a universal truth of the gender divide in the spread of Hallyu can be confirmed in Israel/Palestine and Indonesia. What is interesting is the ethnic divide within the female fans of Hallyu in Israel/Palestine and Indonesia is unusually striking despite the fact that they are victims of sexism in their own male-dominated society. As Table 4 shows, ethnic segregation within the Hallyu fan groups in each region is evident despite the fact that gender discrimination is as universal as the gender divide in Hallyu fandom. In various interviews, I could confirm that ethnic animosity between female Israeli and Palestinian Hallyu fans was strong, although such hatred is much diluted between female Chinese and Javanese Hallyu fans.

Ethnic segregation is manifested by state violence on minority women for their cultural consumption patterns. As Table 4 shows, state violence on Chinese women for defying Islam on the one hand and embracing Western and/or Chinese culture is most obvious, although the Israeli government in Palestine also harshly suppresses the fundamentalist Islamic movement (both male and females). What is striking in our analysis of the four groups of female Hallyu fans in Indonesia and Israel/Palestine is that it is the Islamic women in both countries that are the most ardent followers of Hallyu phenomenon. There has not yet been any state violence reported on the Islamic women who consume Hallyu in large quantities in each country. Furthermore, it is the Indonesian Muslim women who are the strongest and most loyal fans of Hallyu (i.e., the sheer number of club members in Indonesia vis-à-vis other Islam nations).

Table 4: Women's Status in Four Ethnic Communities

\begin{tabular}{|c|c|c|c|c|}
\hline & $\begin{array}{l}\text { Jewish } \\
\text { Women }\end{array}$ & $\begin{array}{l}\text { Palestinian } \\
\text { Women }\end{array}$ & $\begin{array}{l}\text { Javanese } \\
\text { Women }\end{array}$ & $\begin{array}{l}\text { Chinese } \\
\text { Women in } \\
\text { Indonesia }\end{array}$ \\
\hline \multicolumn{5}{|l|}{ Discrimination against } \\
\hline National Level & Yes & Yes & Yes & Yes \\
\hline Ghetto level & $\mathrm{N} / \mathrm{A}$ & Yes & $\mathrm{N} / \mathrm{A}$ & Yes \\
\hline \multicolumn{5}{|l|}{ Tolerance to } \\
\hline $\begin{array}{l}\text { Consuming Western/ } \\
\text { Japanese }\end{array}$ & Yes & Partially & Partially & Yes \\
\hline Islam & Partially & Yes & Yes & Yes/No* \\
\hline Hallyu & Yes & Partially & Partially & Partially \\
\hline
\end{tabular}




\begin{tabular}{|c|c|c|c|c|}
\hline & $\begin{array}{l}\text { Jewish } \\
\text { Women }\end{array}$ & $\begin{array}{l}\text { Palestinian } \\
\text { Women }\end{array}$ & $\begin{array}{l}\text { Javanese } \\
\text { Women }\end{array}$ & $\begin{array}{l}\text { Chinese } \\
\text { Women in } \\
\text { Indonesia }\end{array}$ \\
\hline \multicolumn{5}{|l|}{ State violence on } \\
\hline $\begin{array}{l}\text { Consuming Western/ } \\
\text { Japanese }\end{array}$ & No & Partially & Partially & No \\
\hline Islam & Partially & No & No & No \\
\hline Hallyu & No & Not yet & Not yet & Not yet \\
\hline Local culture among & Strong & Weak & Strong & Medium \\
\hline Hallyu soft power among & Medium & Medium & High & High \\
\hline
\end{tabular}

"Muslims force Islam on Chinese women, whereas Chinese men would not tolerate Chinese women voluntarily becoming Muslims.

Does this mean that Islam, Indonesian regional culture, and the type of state violence are three significant factors that define female Hallyu fandom in Islam societies, as mature age and Japanese local culture were the key factors among East Asian female Hallyu fans? Islam in Palestine and Indonesia is a religious symbol that represents both suppression and liberation. When the Osman Empire occupied Palestine, Islam was a symbol of suppression, although it suddenly turned into a message of liberation when the new Arab nationalism started its political campaign in the region after the Second World War (Naramoto). Likewise, Islam was a message of suppression and invasion to Indonesia during the $17^{\text {th }}$ century, while it worked as a symbol of liberation during the independence movement in alliance with Japanese imperialism against the Dutch forces (Kobayashi). ${ }^{4}$ Therefore, Islam is not a universal but a perplexing religious symbol to Palestinians and Indonesians, who had to fight external invasions and internal political and ethnic divisions and strife throughout its pre-modern and modern history.

Like in Palestine, the regional culture in Indonesia was based on economic affluence, cultural diversity, openness, tolerance to foreign cultures, and massive cultural hybridity. The basis of economic affluence derived from the global trade with long distance merchants from China, Japan, other Southeast Asian countries, India, Arab countries, and even Portugal (Boxer; Andaya). To deal with global commercial trade efficiently, Indonesian rulers in the port cities hired port and trade specialists who migrated into Indonesia from Europe, China, and India. Cosmopolitanism and cultural openness to outer religions were a necessity for the global commercial activities, and consequently, Indonesian rulers had openly embraced Buddhism, Hinduism, Confucianism, Islam, and even Christianity until the Portuguese and Dutch invasions (Hirosue). Cultural hybridity, instead of cultural universalism, was the cultural structure of Islam for Indonesians, whether they were state officials 
or peasants. Be that as it may, hybridized local culture coexisted with the state ideology of Islam that quickly institutionalized and localized the Arabian religious rituals through intellectual and professional communications with Arab religious leaders and scholars (Kobayashi). The subsequent colonial influences from Western Christianity and Japanese elite culture only augmented the diversity of local culture in Indonesia without destroying the fundamental institutional bifurcation between Islam as state ideology or high culture and local culture as subculture.

The Indonesian type of institutional bifurcation was lacking in Palestine, where Islam became both high culture and subculture in the absence of the Palestinian state. After the withdrawal of the Ottoman Empire, as the first Islam state that occupied Palestine based on the suppression of local culture, Palestinians recovered their ethnic identity as Arabs through the rediscovery of Islam as their own religion. Previously, Palestinians had freedom of choosing Islam, Judaism, or Christianity in their own territory, a geographic space that had always been in contention among various external powers. Similar to Indonesia, Palestinians had to accept foreign religions as a means of survival. However, unlike Indonesia, Islam and its sacred Arabic language were not in conflict with local culture, creating no institutional bifurcation between Islam as a state ideology and local culture as subculture (Naramoto). Therefore, as the independence movement raged on during the early $2 \mathrm{O}^{\text {th }}$ century, most Palestinians were converted to Islam. This difference is significant to the extent that it can explain why Indonesia is not only different from other Muslim countries in the Middle East and North Africa, but more ardent than any other Islamic countries in their open consumption of Hallyu among local young women.

A further difference between Indonesia and Palestine is noticeable in the role of Islam as a state ideology. Apart from the fact that Palestine is still in the process of recovering its state from invaders and occupiers, Indonesia's Islam as a state ideology was mobilized not only during its resistance to Western imperialism in its process of building a new state, but harshly applied to the suppression and massacres of its own people during the state-building process, especially against Indonesian Marxists and Chinese immigrants (Aguilar; Heryanto). First and foremost, the Indonesian state builders worked closely with Japanese imperialists in their efforts to eradicate Dutch imperialists, creating an internal cleavage within the military over ideological issues. The military faction led by Sukarno was proJapan in a similar fashion to Subhas Chandra Bose, who worked closely with Nazi Germany and imperial Japan in his fight against the British. The ousting of Sukarno by Suharto was an attempt by a competing military faction to wipe out pro-Japanese Marxists from the new nation. Suharto's state violence on Marxist Indonesians (or anyone he labeled as Marxists) and the Chinese Indonesians, which were carried out mostly by Muslim paramilitary groups, was an attempt by the state to impose 
pure Islam on all Indonesians, even though Islam was not an Indonesian indigenous culture (Mietzner).

State violence on its own people during the modern state building has not existed in Palestine, a very significant deviation from the Indonesian phenomenon, although Palestine can also stage collective violence against particular foreign cultures in a similar fashion to Japan's anti-Hallyu movements. In this sense, both Indonesian Islam and local culture deviate substantially from those of Palestine and the Arab world. Outstanding Indonesian Islam and local culture may explain the highest Hallyu soft power in that country (see Table 3). The key to this Indonesian idiosyncrasy derives from its use of state violence on its own people in order to preserve its Islam high culture vis-à-vis its strong local culture (see Table 5). This idiosyncrasy disappeared in a relatively short period after ousting Suharto from the military government. With the withdrawal of the state violence supported by Islam, Indonesian youths are ardently showing their desire for liberation and freedom by massively consuming foreign culture, including Hallyu. However, it is very unclear, just like the uncertain future of Indonesian democracy, whether the new democratic Islam state would reinstate state terror on young Hallyu fans in the country, who seem very intimidating to the state ideology of Islamic purity, especially among Indonesian women, whether Javanese, Sumatran, or Chinese.

Table 5: State Violence on Foreign Cultures in Indonesia and Palestine

\begin{tabular}{llllllll} 
& Country & $\begin{array}{l}\text { Indigenous } \\
\text { Culture }\end{array}$ & Islam & $\begin{array}{l}\text { Western/ } \\
\text { Christian }\end{array}$ & Marxism & $\begin{array}{l}\text { Japanese } \\
\text { Pop Culture }\end{array}$ & Hallyu \\
\hline Supporters & Indonesia & All & Male, ruling & Chinese & $\begin{array}{l}\text { Male, Urban, } \\
\text { Educated }\end{array}$ & Young & $\begin{array}{l}\text { Female, } \\
\text { Young }\end{array}$ \\
& Palestine & None & All & Rare & $\begin{array}{l}\text { Male, Urban, } \\
\text { Educated }\end{array}$ & $\begin{array}{l}\text { Female, } \\
\text { Young }\end{array}$ & $\begin{array}{l}\text { Female, } \\
\text { Young }\end{array}$ \\
\hline $\begin{array}{l}\text { State } \\
\text { Violence }\end{array}$ & Indonesia & None & On ISIS & On Chinese & Yes & None & Not Yet \\
\hline $\begin{array}{l}\text { Conse- } \\
\text { quence }\end{array}$ & Palestine & N/A & On Hamas & On Jews & None & Not Yet & Not Yet \\
\hline
\end{tabular}


However, whether in Indonesia or Palestine, Islam in general works as a hidden force behind the gender divide (Moghadam; Mir-Hosseini; Douki et al. 2007). Despite democracy and the withdrawal of the Islamic military state, Islam in Indonesia reappeared as a politically neutral national religion that mobilizes the Javanese toward the suppression of non-Islamic ethnic groups in the country. Islam and the craving for feminine freedom are therefore reversely related, as much as Islam is positively related to political dictatorship and gender inequality. Hallyu therefore is a message of hope for the young Islam women in both Palestine and Indonesia, as much as it was a message of melancholia for older Japanese Hallyu fans (Oh, "Torn Between"). While Islam has changed its faces over various historical periods in the two countries, what remained unchanged was women's status under Islam.

\section{HALLYU AND ISLAM STATES - INTERVIEW RESULTS}

The interviews took place in Jakarta and Surabaya, Indonesia in 2013 and 2016, respectively. Most interviewees were female Hallyu fans aged 18 to 40 with a small number of male Hallyu fans (a total of 30 interviewees). The Palestine interviews took place in 2014 with female Hallyu fans only who were mostly college students (aged between 16 and 20) in the West Bank (a total of 10 interviewees). By virtue of "global focused interviews and ethnographic revisits" from 2013 to 2016 (and thus rejecting "car window sociology" with only one or two distant visits without engaging actively with the daily lives of the interviewees), I generated reflexive global ethnographic data either to refute the extant interpretations of the female and/or minority Hallyu fans in Indonesia and Palestine or to reconstruct their minority or gender strife through new theoretical perspectives (see inter alia, Du Bois; Merton et al.; Colson et al.; Geertz, After the Fact; Burawoy, "Introduction," "Revisits").

The interview results with Indonesian and Palestine Hallyu fans support our discussions so far. First and foremost, Indonesian female Hallyu fans love Hallyu because of their strong desire to have more choices over their cultural consumption besides Islam, Chinese, Western, and Japanese mainstream or subculture products. In this regard, most of them feel that Hallyu gives them more pleasure than the competing cultural content from other countries.

My interest in K-pop was raised because they offer what is not provided by other pop music, such as Indonesian or American. The K-pop industry "sells" its artists wholly to fulfill the dreams of their fans. In their stage appearance, K-pop boy bands and girl bands can offer a different package (in the dancing and costume) compared to British 
or American bands. The agencies satisfy the whims of the fans, by holding fan meetings, which are not limited to talk shows, but also complemented with fans getting signatures, handshakes, high fives and even hugs from their idols. These are intended, in my opinion, to bring the artists closer to their fans. K-pop is also sold in various forms of merchandise. In short, the K-pop industry fulfills the dream, but also creates such a dream, among its fans. (Interview with Furi, a female Javanese Islam woman in her mid-2os)

It is easy to tell the difference between K-pop and other pop music because K-pop is more refreshing and joyful, especially during their concerts. [...] K-pop touches my heart directly and it's full of emotions. (Minas, a female Palestinian college student, 20)

Particularly interesting is how these female Hallyu fans in Indonesia and Palestine perceive Korea and Korean women as equally beautiful and want to emulate them (i.e., want to be as pretty and free as Korean women).

I follow my idols news, and I also enjoy seeing the very beautiful natural views of Korea. (Minas) I want to be as pretty as Korean women even if that entails a cosmetic surgery. (Ilona, a Chinese Indonesian Christian female college student) I liked their beauty in everything. They give me hope to have a better future. (Ibtihal, a Palestinian college female)

While not much cultural diversity is found in Palestine, where Islam is the same as local culture, Indonesians consider their ethnic or local culture to be different from Islam.

Korean culture has a lot of values that Islam would also appreciate, such as respecting between people, justice, honoring one's parents. Islam would also appreciate family values. There are a lot of things in Korean culture that are considered precious in Islam. (Maysa, a Palestinian college female)

Maysa finds some aspects of Korean culture to be similar to Islam, although her big premise is that the universal Islam value system is above the particularistic Korean counterpart.

Instead of antagonizing other cultures, Islam in fact calls for knowing other cultures and mixing with them. As Allah said, "Oh mankind, we created you from a single (pair) of a male and female, and we made you into nations and tribes, that you may know each other (not that you may despise each other)." But in that purview, Islam limits this mixing by taking only the useful things from the culture and the things that match with Islam. You should reject what goes against Islam and its values. There are some sides of Hallyu that Islam forbids such as singing and dancing and the intense relationships between the two genders. (Maysa) 
However, among Indonesian Hallyu fans, Korean culture represents different aspects of their diverse ethnic and local cultures.

Korean culture that emphasizes politeness is similar to Indonesian. Koreans also add emphases to keeping manners, good behavior, and not expressing emotions explicitly. These are all commonly found in our culture. (Desideria, a female Christian Javanese Ph.D. student)

Tough women that appear on most Korean dramas are similar to our cultural values. (Ruth, a female Karo Batak college student in Jakarta) The value of working hard is found in both cultures. Also, family ties are strong. (Vicky, a Chinese-Javanese female college student)

Although Desideria, a Christian Javanese woman, judges Korean culture based on her local Islam culture, Ruth, who is a Karo Batak woman, views female "toughness" as an important Korean value, whereas Vicky, who is a Chinese-Javanese woman, highlights Chinese work ethic commonly found in Korean culture. Therefore, the diversity of local culture allows these Indonesian fans to be more assertive and open to foreign cultures than Palestinian women by exploring cultural similarities found in foreign cultures through their own local and ethnic values. Fundamentally, the openness of Indonesian local culture, despite Islam, allows young female Hallyu fans to travel Korea freely, whereas such freedom does not exist in Palestine, where women must travel with their fathers or husbands.

However, Hallyu gives messages of hope to both Indonesian and Palestine female fans. The gender divide in Hallyu consumption leads these young female fans to "forward learning" in the hope of overcoming their gendered melancholia, which is one type of relative deprivation (Butler; Oh, "Torn Between"). For example, Palestinian female Hallyu fans emphasize their desire to escape from Palestine and pursue a new dream of visiting and living in Korea. To them Korea is a seemingly inaccessible destination of an imagined trip, a country that they think is closer to their dreamland than their Palestinian homeland that is devastated and unavoidable. Korea to them is also different from their previously held dreamlands such as neighboring oil rich Arab nations, Europe, or even America. For example, a seventeen-year-old girl from Nablus said: "My only dream is to visit Korea and try everything I wanted to try there."

My Korean knowledge will help me get scholarship to KAIST. I want to learn advanced technological knowledge in Korea and eventually get a job in Indonesia that involves work with Korea. (Rahman, a Javanese Muslim college male) 
Table 6: Local Culture, Islam, and State Violence

\begin{tabular}{|c|c|c|c|}
\hline & & Indonesia & Palestine \\
\hline $\begin{array}{l}\text { Gender } \\
\text { factor }\end{array}$ & $\begin{array}{l}\text { Why love } \\
\text { Hallyu? }\end{array}$ & $\begin{array}{l}\text {-Korean women are so beautiful } \\
\text {-Korea is so beautiful } \\
\text {-Korea is advanced and creative } \\
\text {-Korea has all the family values } \\
\text { that cannot be found in } \\
\text { Indonesia }\end{array}$ & $\begin{array}{l}\text {-Korean women are so pretty } \\
\text {-Korea is so advanced and } \\
\text { beautiful } \\
\text {-Korea has good traditional } \\
\text { values similar to Islam culture }\end{array}$ \\
\hline $\begin{array}{l}\text { Local } \\
\text { culture vs. } \\
\text { Islam }\end{array}$ & $\begin{array}{l}\text { What if } \\
\text { Islam } \\
\text { contradicts } \\
\text { to Hallyu? }\end{array}$ & $\begin{array}{l}\text {-Not much contradiction } \\
\text { between Indonesian culture } \\
\text { and Hallyu } \\
\text {-Some religious values } \\
\text { discourage Hallyu, but not } \\
\text { really controversial even if } \\
\text { we disobeyed some of the } \\
\text { religious values }\end{array}$ & $\begin{array}{l}\text {-Cannot freely travel Korea } \\
\text { without fathers' consent } \\
\text {-Cannot accept active intersex } \\
\text { relations shown on K-pop and } \\
\text { K-drama } \\
\text {-Remain conforming to Islam } \\
\text { values that contradict to Hallyu }\end{array}$ \\
\hline $\begin{array}{l}\text { Views } \\
\text { of state } \\
\text { violence }\end{array}$ & $\begin{array}{l}\text { Fear of } \\
\text { state } \\
\text { violence on } \\
\text { Hallyu fans? }\end{array}$ & $\begin{array}{l}\text {-Given former dictatorship and } \\
\text { rising Islamic fundamentalism } \\
\text { in the government, we fear } \\
\text { state violence on Hallyu fans }\end{array}$ & $\begin{array}{l}\text {-No reason to fear state violence } \\
\text { as Islam appreciates learning } \\
\text { from other cultures }\end{array}$ \\
\hline
\end{tabular}

For Indonesians, studying in Korea comes with a specific plan that can be achievable, unlike the dismal Palestinian dreams held by the fans there. Also, some of the Indonesian fans have already deepened their understanding of Korea by visiting the country over and again.

First, you like K-pop and drama, but as you go deeper, you will like Korean places and travel destinations. They're different from Indonesia; it has four seasons, pretty flowers, and different eco systems. The Korean government takes a good care of tour spots. Also, you get to love Korean food, which is unique and mostly delicious like BBQ beef. Korea is more unique than Japan, because it has North-South conflicts that separated families into North and South. They can meet together only when they get really old. It's all sad. (Gladys, a Chinese Christian college female)

Strong commitment to Islam vis-à-vis local culture as a state ideology of liberation and independence from Western imperialism and Israel allows Palestine Hallyu fans to be free from the paranoia of state violence on them as punishment for violating some of the Islamic fundamentals. However, Islam as a state ideology to purge foreign cultures, especially Western Christianity and Chinese ethnic culture, 
continues to be a source of menace among female Hallyu fans, especially Chinese Hallyu fans, who do not deny their fear of state violence on them in the near future.

Why would the Palestinian government punish Hallyu fans? It would never punish the Hallyu fans. I mean why would it do so? It has no right to do so. Our love for Hallyu belongs to us and no one has anything to do with it. (Maysa)

I fear the Indonesian government might do something to us. That also depends on how well Koreans polish their pop culture not to anger Muslims in my country. For example, I heard that there is one K-pop singer who wears hijab. Maybe, she can be a spokesperson or an ambassador between K-pop and Islam. Just prepare a pray room for Muslims during K-pop concerts or cultural events. Koreans need to be cautious to make the whole process smooth and peaceful. (Xena, a Christian Chinese female in the mid-2os)

\section{CONCLUSION}

State violence against particular cultures of foreign origin or groups of immigrants who hold foreign cultural values has been common in pre-modern and modern human history (Tilly, The Politics, "Terror”; Lie). However, violence against the female population for consuming unacceptable foreign cultures or mating with foreign males has not been widely noticed or studied historically (Watts and Zimmerman). Hallyu is a new global cultural phenomenon that is based on the gender divide and therefore is a potential target of state and social violence. On top of these important developments surrounding the Hallyu phenomenon, the Korean government has tried to promote Hallyu as a new Korean soft power based on wrong information and understanding of the new pop culture phenomenon, further exacerbating the anti-Hallyu sentiments among elite and male groups in various societies where Hallyu is popular.

In this paper, I tried to chart out the basic structure of the Hallyu phenomenon in two widely different Islam societies of Palestine and Indonesia, focusing on the gender divide and state violence as two key concepts of this study. Although both Indonesia and Palestine embraced Hallyu as a new foreign cultural import in their cultural market that has already been inundated with Islam, Western, and Japanese cultural icons and products, the two countries present widely different patterns of Hallyu fandom. While Indonesia is the largest Islam nation in the world that has the largest female Hallyu fans in Southeast Asia, Palestine is the smallest Islam internal colony within the state of Israel with the smallest number of female Hallyu fans. Although strong Indonesian local culture and ethnic diversity allowed the 
creation of quick and large fandom, it has also ignited internal worries among male Islamic groups of the nation who want to curtail female Hallyu fandom in their country to protect Islamic fundamentals.

This is why we need to look at both Islam and local culture in the analysis of the gender divide in global cultural hybridity. Islam in Indonesia means oppression by the male rulers who proactively adopted a foreign religion from Arabia or the Middle East, whereas it denotes resistance against all historical forms of external oppression onto local people in Palestine. Islam remains an indigenous culture for Arab people in Palestine, whereas it is a foreign culture in Indonesia. Therefore, Islam in Indonesia is closely related to state violence against those who resisted Islam, whereas it resonates with liberation from Western and Israeli repression in Palestine. However, in both countries, Islam universally works as a sexist ideology that has suppressed women, forcing them to seek gender liberation apart from national liberation. Therefore, for Indonesians, Hallyu is another cultural choice for women who enjoy newly gained democracy and chances of realizing forward learning, whereas for Palestinians, Hallyu is an ultimate hope of realizing their suppressed expression of ressentiment. This means that in Palestine, female Hallyu fans cannot openly criticize Islam for their ill fate, although loving Hallyu is permitted without the fear of state violence. Indonesian female Hallyu fans can easily drop Hallyu if state violence, similar to the previous massacres of Marxists and Chinese, creeps in.

Islam societies present an enigma especially when local culture interacts with Islam. However, future cultural studies of Islam societies must continue to look at both poles of local culture and Islam in order to understand a complex web of the gender divide in the consumption of foreign cultures. State violence also continues to affect cultural consumption patterns in global hybrid communities, an important topic that needs to be pursued in the future. 


\section{Notes}

* This work was supported by the Policy-Oriented Research Grant (2016) generously provided by the Korea Foundation.

1. In this paper, a Muslim country or nation refers to a state where the majority population are Islamic believers.

2. Although learning motivations are important in determining Hallyu fandom in the current global world system, I will not discuss the topic in detail in this paper. For an in-depth analysis of Hallyu motivations, see inter alia, Oh, "Hallyu," "Torn Between"; Oh and Park.

3. Although it was the Javanese themselves who openly embraced Islam or initiated the process of Islamization of Indonesia since the $17^{\text {th }}$ century, those who needed Islam the most were the wealthy merchants and politicians in the court who controlled global trade with Arabs. The local abagan (peasants) did not accept the new religion until independence (see Geertz, The Religion of Java). 


\section{Works Cited}

Aguilar, Filomeno V. "Citizenship, Inheritance, and the Indigenizing of 'Orang Chinese in Indonesia." Positions: East Asia Cultures Critique, vol. 9, no. 3, 2001, pp. 501-533.

Andaya, L. Y. The World of Maluku: Eastern Indonesia in the Early Modern Period. U of Hawaii P, 1993.

Anholt, Simon. "Editorial." Place Branding and Public Diplomacy, vol. 6, no. 1, 2010, pp. 1-10.

BBC: World Service. 2013. "Views of China and India Slide While UK's Ratings Climb: Global Poll," http://www.worldpublicopinion.org/pipa/2013\%2oCountry\%2oRating\%2o Poll.pdf. Accessed 25 Apr. 2014.

Boxer, C. R. Portuguese Conquest and Commerce in Southeast Asia, 150o-1750. Ashgate, 1990.

Burawoy, Michael. "Introduction: Reaching for the global." Global Ethnography: Forces, Connections, and Imaginations in a Postmodern World, edited by Burwoy, M. et al., U of California P, 200o, pp. 1-40.

--. "Revisits: An outline of a theory of reflexive ethnography." American Sociological Review 68.5 (2003): 645-679.

Butler, Judith. Gender Trouble: Feminism and the Subversion of Identity. Routledge, 2011.

Carvalho, Christina. Christiaan Snouck Hurgronje: Biography and Perception. Master's Thesis. University of Amsterdam, 2010.

Colson, Elizabeth, et al. "Long-Term Field Research in Social Anthropology". Current Anthropology, vol. 17, no. 3, 1976, pp. 494-496.

Cooper, Andrew Fenton, Richard A. Higgott, and Kim Richard Nossal. Relocating Middle Powers: Australia and Canada in a Changing World Order. U of British Columbia P, 1993.

Douki, S., et al. "Women's mental health in the Muslim world: Cultural, religious, and social issues." Journal of Affective Disorders, vol. 102, no. 1, 2007, pp. 177-189.

Doumani, Beshara. Rediscovering Palestine: Merchants and Peasants in Jabal Nablus, 170o190o. U of California P, 1995.

Du Bois, W. E. B. The Philadelphia Negro. U of Pennsylvania P, [1899]1996.

El Feki, Shereen. Sex and the Citadel: Intimate Life in a Changing Arab World. Anchor Books, 2013.

Elfving-Hwang, Joanna. "South Korean Cultural Diplomacy and Brokering 'K-Culture' Outside Asia." Korean Histories, vol. 4, no. 1, 2013, pp. 14-26.

Floyd, Jr., Samuel A. The Power of Black Music: Interpreting Its History from Africa to America. Oxford UP, 1995.

Geertz, Clifford. After the Fact. Vol. 5. Harvard UP, 1996.

--. Islam Observed, Religious Development in Morocco and Indonesia. U of Chicago P, 1968.

--. "The Javanese Kijaji: The Changing Role of a Cultural Broker." Comparative Studies in Society and History, vol. 2, no. 2, 1958, pp. 228-249.

-.. The Religion of Java. U of Chicago P, 1960. 
Gries, Peter Hays, Jennifer L. Prewitt-Freilino, Luz-Eugenia Cox-Fuenzalida, and Qingmin Zhang. "Contentious Histories and the Perception of Threat: China, the United States, and the Korean War-an Experimental Analysis." Journal of East Asian Studies, vol. 9, no. 3, 2009, pp. 433-65.

Hall, Ian and Frank Smith. "The Struggle for Soft Power in Asia: Public Diplomacy and Regional Competition." Asian Security 9, 2013, pp. 1-18.

Hall, Joshua. 2013. "Yesanman Nangbihan Heouljoeun 'Hansik Segyehwa”' ['Globalization of Korean Food' Only Window Dressing That Wasted a Big Budget]. Wall Street Journal, http://realtime.wsj.com/korea/2013/05/22/. Accessed 25 Apr. 2014.

Han, Youngkyun. "Nihon ni okeru Kanryūgenshō to Kankoku no Kanryū ni Taisuru Ninshiki" [the Hallyu Phenomenon in Japan and the Perception of Hallyu in Korea]. Master's Thesis. Waseda University. 2013.

Heryanto, Ariel. State Terrorism and Political Identity in Indonesia: Fatally Belonging. Routledge, 2006.

Heryanto, Ariel and Vedi Hadiz. "Post-Authoritarian Indonesia: A Comparative Southeast Asian Perspective." Critical Asian Studies, vol. 37, no. 2, 2005, pp. 251-275.

Hirosue, Masashi. Tōnan Ajia no Kōshisekai: Chiikishakai no Keisei to Sekaichitsujo. Iwanamishoten, 2004.

Huang, Xiaowei. "Korean Wave: The Popular Culture Comes as Both Cultural and Economic Imperialism in East Asia." Asian Social Science 5, 2009, pp. 123-30.

Hübinette, Tobias. "The Reception and Consumption of Hallyu in Sweden: Preliminary Findings and Reflections." Korea Observer, vol. 43, no. 3, 2012, pp. 503-525.

Hwang, Seong Bin. "Net Uik gwa Banhanryu Baewoejueui eui Yeoron: Juyoeonron eui Damronbunseok eul Jungsimeuro" [the Net Rightwing, Anti-Hallyu, and Xenophobic Mass Media: With a Focus on the Discourse Analysis of Major Mass Media]. Ilbon Bipyeong 10, 2014, pp. 124-63.

Iwabuchi, Koichi. Resilient Borders and Cultural Diversity: Internationalism, Brand Nationalism, and Multiculturalism in Japan. Lexington, 2015.

Kim, Andrew Eungi, Fitria Mayasari, and Ingyu Oh. "When 'Tourist' Audiences Encounter Each Other: K-pop Fans and Transnational Identity Building." Korea Journal, vol. 53, no. 4, 2013, pp. 59-82.

Kobayashi, Yasuko. "Indonesia isuramu kenkyū no hanseiki: tsiiki kenkyū to isuramugaku tono hazama." Tönaajia Kenkyū, vol. 37, no. 2, 1999, pp. 176-193.

KOFICE. 2013 Hallyu White Paper. Seoul: KOFICE. 2014.

Korea Foundation. Jiguchon Hallyu Hyeonhwang. Korea Foundation, 2014-2016.

Lev, Daniel S. The Transition to Guided Democracy: Indonesian Politics, 1957-1959. Equinox, 2009.

Lie, John. Modern Peoplehood. Harvard UP, 2004.

--.. "Why Didn't "Gangnam Style" Go Viral in Japan?: Gender Divide and Subcultural Heterogeneity in Contemporary Japan." Cross-Currents: East Asian History and Culture Review, 9, 2013, pp. 44-67.

Merton, Robert K., and Patricia L. Kendall. "The Focused Interview." American Journal of Sociology, vol. 51, no. 6, 1946, pp. 541-557. 
Mietzner, Marcus. Military Politics, Islam, and the State in Indonesia: From Turbulent Transition to Democratic Consolidation. Institute of Southeast Asian Studies (ISEAS), 2009.

Mir-Hosseini, Ziba. "Muslim Women’s Quest for Equality: Between Islamic Law and Feminism." Critical Inquiry, vol. 32, no. 4, 2006, pp. 629-645.

Moghadam, Valentine M. "The Reproduction of Gender Inequality in Muslim Societies: A case study of Iran in the 1980s." World Development, vol. 19, no. 10, 1991, pp. 1335-1349.

Nakamura, Mitsuo. "Bunmei no jinruigakusaiko: Isuramu bunmei no baai." Gendai no Shakaijinruigaku 3: Kokka to Bunmei no Katei, edited by Itō Abito et al., Tokyo UP, 1987, pp. 109-138.

Naramoto, Eisuke. Paresuchina no Rekishi. Akashishoten, 2005.

Oh, Ingyu. "Hallyu: The Rise of Transnational Cultural Consumers in China and Japan." Korea Obeserver, vol. 40, no. 3, 2009, pp. 425-459.

-.. " Torn Between Two Lovers: Retrospective Learning and Melancholia among Japanese Women." Korea Observer, vol. 42, no. 2, 2011, pp. 223-254.

Oh, Ingyu and Choong-Mook Lee. "A League of their Own: Female Supporters of Hallyu and Korea-Japan Relations." Pacific Focus, vol. 24, no. 2, 2014, pp. 284-302.

$\mathrm{Oh}$, Ingyu and Gil-Sung Park. "From $\mathrm{B}_{2} \mathrm{C}$ to B2B: Selling Korean Pop Music in the Age of New Social Media." Korea Observer, vol. 43, no. 3, 2012, 365-397.

Otmazgin, Nissim and Irina Lyan. "Hallyu across the Desert: K-pop Fandom in Israel and Palestine." Cross-Currents: East Asian History and Culture Review, vol. 3, no. 1, 2014, pp. 32-55.

Salameh, Mamdouh G. "Quest for Middle East oil: the US versus the Asia-Pacific Region.” Energy Policy, vol. 31, no. 11, 2003, pp. 1085-1091.

Samson, Allan A. "Islam in Indonesian Politics." Asian Survey, vol. 8, no. 12, 1968, pp. 1001-1017.

Sohn, Yul. "Middle Powers Like South Korea Can't Do without Soft Power and Network Power." Global Asia 7, 2012, pp. 27-34.

Steenbrink, Karel. "Dari Kumpul Kebo di Samoa hingga A bangan di Pare." PanJi Masyallakat 508, 1986, pp. 72-74.

Suryadinata, Leo. Elections and Politics in Indonesia. Institute of Southeast Asian Studies, 2002.

Tilly, Charles. The Politics of Collective Violence. Cambridge UP, 2003.

-.. "Terror, Terrorism, Terrorists." Sociological Theory, vol. 22, no. 1, 2004, pp. 5-13.

Tsutsiya, Kenji. "Culturalism ni tsuite." Tōnanajia: Rekishi to Bunka 22 1993, pp. 201-218.

Watts, Charlotte, and Cathy Zimmerman. "Violence against Women: Global Scope and Magnitude." The Lancet, vol. 359, no. 9313, 2002, pp. 1232-1237. 